\title{
Serological investigations for evidence of an infectious aetiology of rheumatoid arthritis
}

\author{
ROBERT W. CHANDLER, HARRY ROBINSON, AND ALFONSE T. MASI
}

From the Rheumatology Section of the Department of Medicine, University of Tennessee School of Medicine, Memphis, Tennessee

The possibility that rheumatoid arthritis (RA) has an infectious aetiology has spurred many attempts at the identification of such agents. Early work centred in a possible relationship of RA and streptococcal infection was stimulated by the report of Cecil, Nicholls, and Stainsby (1930). More recently, Mycoplasma have been investigated by isolation and serological techniques (Bartholomew, 1967; Barnett, Balduzzi, Vaughan, and Morgan, 1966). Also, diphtheroid organisms and bacterial L-forms have been reported to be associated with RA (Duthie, Stewart, Alexander, and Dayhoff, 1967). Transmission of a form of arthritis by the inoculation of newborn mice with RA synovial membrane extracts has been claimed by Warren, Marmor, Liebes, and Hollins (1969). Differences in susceptibility of RA and normal synovial membrane cell cultures to Newcastle disease virus infection have been interpreted as due to a pre-existing infection of the RA synovial membrane (Smith and Hamerman, 1968). New and varied techniques are being utilized to search for 'slow' viruses and other agents in many of the connective tissue diseases, but these efforts have thus far yielded equivocal or negative results (Fresco, 1968; Norton, Velayos, and Robison, 1970). Sporadic positive reports have not usually been confirmed by later investigators. Yet, in spite of the contradictory findings in the literature, one of the most commonly accepted theories is that an infectious agent may trigger a cycle of events which leads to RA.

Our group is currently conducting a long-term follow-up study of patients with early RA and other connective tissue diseases (Masi, Robinson, and Hughen, 1968). Briefly, the criteria for admission of a patient into this study are:

(1) Age less than 45 years;

(2) First physician diagnosis and referral to study within 6 months;

(3) Residence within the county of Shelby, Tennessee.
Normal controls, matched for age, race, and sex, have been secured for the study patients. Among the many laboratory tests conducted on the patients and controls, are serological determinations of infectious disease antibody titres on the first blood specimen taken. This report is an analysis of the results on our first 22 RA patients and controls.

\section{Material and methods}

PATIENT SERA

Blood specimens taken on the first visit of RA patients to our Arthritis Research Programme outpatients clinic were used in this study. Sera were separated from the clot within 1 to 2 hours and frozen at $-20^{\circ} \mathrm{C}$. in aliquots with portions also lyophilized. The tests described below were performed on frozen specimens of recently obtained sera, and on lyophilized specimens of those obtained more than 3 months before testing. The latex-fixation method of Singer and Plotz (1956) was used to test for rheumatoid factor (RF) in RA patients.

\section{CONTROL SERA}

The normal control sera were mostly taken from patients of the City of Memphis Hospital fracture clinic and from University of Tennessee employees. Matching was done by age ( \pm 5 years), sex, and race. One Negro normal female served as control for one white RA female; otherwise matching was complete. Control sera were treated the same as patient sera.

ANTIGENS AND REFERENCE SERA

These were obtained from commercial sources (Flow Laboratories, Rockville, Maryland; Difco Laboratories, Detroit, Mich.; Microbiological Associates, Bethesda, Md.; and Markham Laboratories, Chicago, Ill.). The sources of the various antigens are indicated in Tables II, III, and IV.

\section{SEROLOGICAL PROCEDURES}

Most of the agglutination procedures were carried out as slide agglutination tests according to the procedures recommended by the supplier of the antigens. The heterophil test for sheep erythrocyte antibodies was done as a tube test (Wintrobe, 1961). The rubella haemag- 
glutination inhibition (HAI) test was carried out in Microtiter equipment (Stewart, Parkman, Hopps, Douglas, Hamilton, and Meyer, 1967). The cold agglutination titrations were performed by the technique of Finland, Peterson, Allen, Samper and Barnes (1945), except that all volumes were reduced and Microtiter equipment was used. The reading of the cold agglutinin titres, after overnight incubation in the cold, was done by gently inverting the plates three times and observing for clumping on the Microplate reading mirror.

Complement fixation (CF) was done in Microtiter equipment, using two units of antigen, as determined by block titrations, and two full units of guinea-pig complement (Flow Laboratories, Grade A, Lyophilized) (Fiset, 1964). The primary incubation of antigen, serum, and complement was for 1 hour at $37^{\circ} \mathrm{C}$., followed by the addition of sensitized sheep erythrocytes. The plates were then incubated for $45 \mathrm{~min}$. at $37^{\circ} \mathrm{C}$. with one agitation during this period. All plates were then centrifuged and read for haemolysis.

A serum was recorded as reactive when any level of antibody reactivity was observed and not just at the accepted diagnostic levels routinely used in the test under consideration. RA and control sera were titrated at the same time, using single lots of the various biologicals, and were read without knowledge of the serum source.

STATISTICAL ANALYSIS

This was done first by determining if there were signifcant differences in the proportions of subjects with reactive titres between the RA group and the normal control group. Secondly, the random ' $t$ ' test was used after logarithmic transformation of the titres, to test whether there were significant differences between the mean titres of the reactive sera in the two groups. Geometric mean titres are shown in Tables III and IV. The ' $t$ ' test cannot be used when there are less than two positive observations per group and such instances are identified by dashes in the Tables.

\section{Results}

The characteristics of the RA and control groups are shown in Table I. The two groups differed only slightly in terms of demographic variables. The RA patients had a median duration from the onset of the first symptoms of arthritis to the serum collection of 5 months (range 6 weeks to 78 months), and a median interval from first physician diagnosis to serum collection of 2 months (range 2 to 6 months). All patients had a diagnosis of either rheumatoid arthritis (two classical, thirteen definite, and three probable) or juvenile rheumatoid arthritis (three definite, one probable) by American Rheumatism Association criteria (Ropes, Bennett, Cobb, Jacox, and Jessar, 1958; Bywaters, 1968).

Twelve of the thirty antigens used yielded completely non-reactive results with both the RA and control sera (Table II).

Table III (opposite) shows the test results with thirteen antigens yielding reactive titres but with no significant differences found between the groups.

Significant differences between the RA and control groups were found with the five antigens shown in

Table I Age, sex, and race distributions of new rheumatoid patients and controls

\begin{tabular}{|c|c|c|c|c|c|c|c|}
\hline \multirow[t]{2}{*}{ Type of subject } & \multirow[t]{2}{*}{ No. of subjects } & \multicolumn{2}{|c|}{ Age (yrs) } & \multicolumn{2}{|c|}{ Sex } & \multicolumn{2}{|l|}{ Race } \\
\hline & & Mean & 2 Std. Errors & $\mathbf{M}$ & $F$ & White & Negro \\
\hline New rheumatoid & 22 & 26.9 & 4.62 & 3 & 19 & 14 & 8 \\
\hline Normal & 22 & $24 \cdot 9$ & $4 \cdot 12$ & 3 & 19 & 13 & 9 \\
\hline
\end{tabular}

Table II Twelve antigens yielding all non-reactive titres with new $R A$ patient and normal control sera

\begin{tabular}{lll}
\hline Type of antigen & Type of test & Titres** \\
\hline Lymphocytic choriomeningitis (1)* & CF & Negative \\
Salmonella Ha (2) & Negative \\
Rickettsial pox (1) & CF. & Negative \\
Heterophil & Negative \\
Mycoplasma salivarium (3) & CF & Negative \\
Mycoplasma hominis 1 (3) & CF & Negative \\
Mycoplasma fermentans (3) & CF & Negative \\
Mycoplasma orale 2 (3) & CF & Negative \\
Mycoplasma arthritidis (3) & CF & Negative \\
Mycoplasma pulmonis (3) & CF & Negative \\
Mycoplasma laidlawii (3) & CF & Negative
\end{tabular}

* Supplier in parentheses: (1) Markham Laboratories. (2) Difco Laboratories.
** All negative except for standard positive reference sera. $\mathrm{CF}=$ complement fixation. Agg. = agglutination. 
Table IV. In a comparison of the results with Salmonella $\mathrm{Hb}$ and Hd antigens, it was determined that serum antibody titres to the antigens correlated significantly $(\mathrm{P}<0.01)$. The Proteus $\mathrm{OXK}$ and $\mathrm{OX} 2$ antibody test results did not show any correlation. In the Proteus OXK test, the RA patients had a significantly lower proportion of reactive titres than the normal group, but in terms of reactive titres RA patients had a significantly higher mean titre than the normal controls. With the Proteus OX2 test, RA patients again had a significantly lower proportion of reactive titres than normal subjects, but the mean titres of reactive tests in the two groups did not differ significantly. In the test for Herpes virus hominis antibodies using tissue-culture derived antigen, the proportions of reactive titres in the two groups did not differ significantly, although the RA patients had a significantly higher mean titre. $\chi^{2}$ tests showed no significant correlations between presence or absence of a positive latexfixation test in RA patients and a reactive antibody titre to the antigens in Table IV. In addition, no significant differences were found by the ' $t$ ' test in reactive mean titres when rheumatoid factor positive and negative RA patients were compared. No significant associations were found between titres of antibodies to antigens in Tables III and IV and the intervals from either onset of symptoms or from first medical diagnosis of RA. By the analysis of variance test, it was determined that the log titres of the serological tests did not differ significantly by the season of the year in which the serum samples were collected.

\section{Discussion}

Our negative results with the Mycoplasma antigens

Table III Thirteen antigens yielding no significant differences in reactions with new rheumatoid and normal control sera

\begin{tabular}{|c|c|c|c|c|c|c|c|}
\hline \multirow[t]{2}{*}{ Type of antigen } & \multirow{2}{*}{$\begin{array}{l}\text { Type } \\
\text { of } \\
\text { test }\end{array}$} & \multicolumn{2}{|c|}{$\begin{array}{l}\text { Numbers of subjects } \\
\text { with reactive titres }\end{array}$} & \multirow{2}{*}{$\begin{array}{l}P \\
\text { value } \\
\chi^{2} \\
\text { test }\end{array}$} & \multicolumn{2}{|c|}{$\begin{array}{l}\text { Geometric mean titres of } \\
\text { reactive tests }\end{array}$} & \multirow{2}{*}{$\begin{array}{l}P \\
\text { value } \\
' t '{ }^{\prime} \\
\text { test }\end{array}$} \\
\hline & & $\begin{array}{l}22 \\
\text { new } \\
\text { rheumatoids }\end{array}$ & $\begin{array}{l}22 \\
\text { normals }\end{array}$ & & $\begin{array}{l}\text { new } \\
\text { rheumatoids }\end{array}$ & normals & \\
\hline $\begin{array}{l}\text { Salmonella 0 (2)* } \\
\text { Erysipelothrix insidiosa (2) } \\
\text { Leptospira pool-1 (2) } \\
\text { Leptospira pool-3 (2) } \\
\text { Cold Agglutinins } \\
\text { Proteus OX19 (2) } \\
\text { Brucella abortus (2) } \\
\text { Rubella (4) } \\
\text { Psittacosis (1) } \\
\text { Mumps (4) } \\
\text { Mycoplasma orale 1 (3) } \\
\text { Adenovirus (4) } \\
\text { Cytomegalovirus (4) }\end{array}$ & $\begin{array}{l}\text { Agg. } \\
\text { Agg. } \\
\text { Agg. } \\
\text { Agg. } \\
\text { Agg. } \\
\text { Agg. } \\
\text { Agg. } \\
\text { HAI } \\
\text { CF } \\
\text { CF } \\
\text { CF } \\
\text { CF } \\
\text { CF }\end{array}$ & $\begin{array}{r}2 \\
0 \\
1 \\
1 \\
1 \\
1 \\
0 \\
19 \\
22 \\
5 \\
1 \\
9 \\
13\end{array}$ & $\begin{array}{r}6 \\
1 \\
2 \\
0 \\
0 \\
1 \\
1 \\
22 \\
22 \\
4 \\
1 \\
7 \\
15\end{array}$ & $\begin{array}{l}\text { NS } \dagger \\
\text { NS } \\
\text { NS } \\
\text { NS } \\
\text { NS } \\
\text { NS } \\
\text { NS } \\
\text { NS } \\
\text { NS } \\
\text { NS } \\
\text { NS } \\
\text { NS } \\
\text { NS }\end{array}$ & $\begin{array}{l}1: 80 \\
\text { All neg. } \\
1: 16 \\
1: 32 \\
1: 20 \\
1: 160 \\
\text { All neg. } \\
1: 288 \\
1: 13 \cdot 2 \\
1: 2 \cdot 3 \\
1: 8 \\
1: 8 \\
1: 11 \cdot 6\end{array}$ & $\begin{array}{l}1: 50 \\
1: 50 \\
1: 16 \\
\text { All neg. } \\
\text { All neg. } \\
1: 20 \\
1: 20 \\
1: 513 \\
1: 8 \cdot 8 \\
1: 2 \cdot 8 \\
1: 4 \\
1: 17 \cdot 7 \\
1: 10 \cdot 5\end{array}$ & $\begin{array}{l}\text { NS } \\
= \\
= \\
\bar{Z} \\
\overline{N S} \\
\text { NS } \\
\text { NS } \\
\overline{N S} \\
\text { NS }\end{array}$ \\
\hline (4) & & $\begin{array}{l}\text { ories. } \\
\text { 11 Associates. } \\
\text { ries. }\end{array}$ & & $\begin{array}{l}+\underset{+N S}{\text { NF }} \\
\text { Agg. } \\
\text { HAI }\end{array}$ & $\begin{array}{l}\text { mpenction } \\
\text { glutination. } \\
\text { lemagglutina }\end{array}$ & $\begin{array}{l}0 \cdot 05 \\
\text { hibition. }\end{array}$ & \\
\hline
\end{tabular}

Table IV Five antigens yielding statistically significant differences in reactions with new rheumatoid and control sera

\begin{tabular}{|c|c|c|c|c|c|c|c|}
\hline \multirow[t]{2}{*}{ Type of antigen } & \multirow{2}{*}{$\begin{array}{l}\text { Type } \\
\text { of } \\
\text { test }\end{array}$} & \multicolumn{2}{|c|}{$\begin{array}{l}\text { Numbers of subjects } \\
\text { with reactive titres }\end{array}$} & \multirow{2}{*}{$\begin{array}{l}P \\
\text { value } \\
\chi^{2} \\
\text { test }\end{array}$} & \multicolumn{2}{|c|}{$\begin{array}{l}\text { Geometric mean titres of } \\
\text { reactive tests }\end{array}$} & \multirow{2}{*}{$\begin{array}{l}P \\
\text { value } \\
\text { ' } t \text { ' } \\
\text { test }\end{array}$} \\
\hline & & $\begin{array}{l}22 \\
\text { new } \\
\text { rheumatoids }\end{array}$ & $\begin{array}{l}22 \\
\text { normals }\end{array}$ & & $\begin{array}{l}\text { New } \\
\text { rheumatoids }\end{array}$ & Normals & \\
\hline $\begin{array}{l}\text { Salmonella } \mathrm{Hb}(1)^{*} \\
\text { Salmonella Hd (1) } \\
\text { Proteus OXK (1) } \\
\text { Proteus OX2 (1) } \\
\text { Herpes virus hominis (2) }\end{array}$ & $\begin{array}{l}\text { Agg. } \\
\text { Agg. } \\
\text { Agg. } \\
\text { Agg. } \\
\text { CF }\end{array}$ & $\begin{array}{r}0 \\
1 \\
7 \\
5 \\
12\end{array}$ & $\begin{array}{r}8 \\
11 \\
20 \\
15 \\
12\end{array}$ & $\begin{array}{l}<\cdot 01 \\
<.01 \\
<\cdot 01 \\
<.01 \\
\mathrm{NS} \dagger\end{array}$ & $\begin{array}{l}\text { All neg. } \\
1: 320 \\
1: 195 \\
1: 70 \\
1: 17\end{array}$ & $\begin{array}{l:l}1 & : 104 \\
1 & : 249 \\
1 & 70 \\
1 & : 116 \\
1 & : 6 \cdot 4\end{array}$ & $\begin{array}{l}\bar{Z} \\
\overline{<} \cdot 01 \\
\mathrm{NS} \\
<\cdot 01\end{array}$ \\
\hline
\end{tabular}

- Supplier in parentheses: (1) Difco Laboratories.

(2) Flow Laboratories.

$\dagger$ NS $=$ not significant; $P>0.05$

AgF. = agglutination. 
contrasted with those of Bartholomew (1967), who found an increased prevalence of reactive titres in the sera of RA patients compared to normal controls. His Mycoplasma antigen consisted, however, of a mixture of fresh isolates, including those from RA, Reiter's syndrome, and systemic lupus erythematosus patients. Also, he tested sera from chronic advanced RA patients in contrast to the newly-diagnosed RA patients in our panel. It would be anticipated that any causal relationship of an infectious agent with RA would be best identified early in the disease. Other investigators have not confirmed Bartholomew's results (Barnett and others, 1966; Sharp, 1970). However, his finding may reflect:

(1) A progressive susceptibility of certain RA patients to infection by Mycoplasma which may be related to the duration of the disease;

(2) The utilization of organisms containing antigens not found in standard strains from commercial sources.

The data presented here are in contrast to those of Smiley and Casey (1969) who report both a lower prevalence and a lower geometric mean titre of antibodies in RA patients for cell culture derived Herpes virus hominis antigen compared with controls. In addition they found an even lower proportion of $H$. hominis antibodies in RA patients as compared to normal controls using egg-derived antigen. Their data also demonstrated that RA patients have a reduced capacity for lymphocyte transformation when stimulated by $H$. hominis antigen. They found no significant differences between RA patients and normal subjects to five other virus antigens, four of which are included in our panel of antigens. Our results were also negative for these four antigens. Our data show that, to a cell-culture derived $H$. hominis antigen, the proportions of reactive antibodies were equal in early RA and controls, but the mean titre was significantly greater in RA patients than in controls. Smiley (1970) defined his RA patients as having long-standing disease. The selected immunological defect in the immune response to $H$. hominis postulated by Smiley and Casey may reflect some phenomenon related to duration of disease. It is interesting that the recent work of Simsarian, Roth, Hopps, Douglas, Williams, and Meyer (1970) also shows a reduced prevalence of $\boldsymbol{H}$. hominis antibodies in an undefined panel of RA patients. They found, as did Smiley and Casey, that the addition of a high titred RF serum to positive $H$. hominis sera from either the RA or the control groups, could depress the antibody titre to $H$. hominis. However, neither group presented data to show any relationship between the level of $H$. hominis antibody titre and the natural occurrence or absence of RF. Our data from new RA patients show no correlation between RF and $H$. hominis antibodies.
It is tempting to attribute the low prevalence of Salmonella and Proteus OX antibodies in RA to an immunological deficiency or hypo-reactivity as others have done with other antigens (Epstein and Jessar, 1959; Rawson, Abelson, and McCarty, 1961 ; Houba, Adam, Malaček, and Tesárek, 1964). However, there are a number of reports which have demonstrated hyper-reactivity (Houba and others, 1964; Meiselas, Zingale, Lee, Richman, and Siegel, 1961; Ascari and Gorman, 1969) as well as no alteration from the normal immune response in RA patients (Shearn, Epstein, and Engleman, 1963; Waller, Ellman, and Toone, 1966; Rhodes, Scott, Markham, and Monk-Jones, 1969). The possibility also exists that the reduced prevalence of Salmonella and Proteus OX antibodies in RA might have resulted from the induction of immunological tolerance by these or related antigens. Immunological tolerance may be induced by high doses of antigen, best accomplished during the neonatal period, or by repeated subimmunogenic doses of soluble and relatively nonphagocytizable antigen. This tolerance is usually of finite duration but may be prolonged by periodic injections of the antigen. A slow or defective infectious agent may possibly be inducing tolerance to itself and related antigens. Such tolerance to virus has been demonstrated in the lymphocytic choriomeningitis virus infections in mice (Hotchin, 1962).

The results of Barnett and others (1966), who mainly used chronic RA patients, were extended and supported by our data which is based on newlydiagnosed RA patients and normal controls. Our data did not demonstrate a causal relationship between the infectious agents studied and RA. The data may possibly be consistent with a selected immunological alteration during early RA.

\section{Summary}

Using a panel of thirty infectious disease antigens and testing sera from 22 newly-diagnosed RA patients and 22 controls, no evidence of a causal relationship with RA was detected by serological means. Of the thirty antigens, 25 showed either no reactivity with RA and control sera, or no significant differences between the two groups. In contrast to other reports in the literature, Herpes virus hominis antibodies were found in equal proportions in RA patients and controls. Also, we found a significantly higher mean antibody titre to $H$. hominis in early RA compared to controls.

A significantly reduced prevalence of reactive titres was found in early RA compared to controls using Salmonella $\mathrm{Hb}$ and $\mathrm{Hd}$ antigens, and Proteus OXK and OX2 antigens. The serum reactivity to Salmonella $\mathrm{Hb}$ and $\mathrm{Hd}$ antigens was significantly 
correlated but such correlation did not exist with the Proteus antigens.

The possibility of selected immunological altera- tions and tolerance in early RA was discussed.

The excellent technical assistance of Mrs. Margaret Dugger is most gratefully acknowledged.

\section{References}

AsCarI, W. Q., AND GoRman, J. G. (1969) Transfusion (Basel), 9, 35 (Hemagglutinating antipenicillin antibodies (HAPA). Incidence and significance in four groups of patients).

Barnett, E. V., Balduzzi, P., Vaughan, J. H., ANd Morgan, H. R. (1966) Arthr. and Rheum., 9, 720 (Search for infectious agents in rheumatoid arthritis).

Bartholomew, L. E. (1967) Ann. N.Y. Acad. Sci., 143, 522 (Characterization of mycoplasma strains and antibody studies from patients with rheumatoid arthritis).

Bywaters, E. G. L. (1968) in 'Population Studies of the Rheumatic Diseases', ed. P. H. Bennett and P. H. N. Wood, p. 455. Elzevier, Amsterdam.

Cecil, R. L., Nicholls, E. E., AND Stainsby, W. J. (1930) Amer. J. Path., 6, 619 (Characteristics of streptococci isolated from patients with rheumatic fever and chronic infectious arthritis).

Duthit, J. J. R., Stewart, S. M., AleXander, W. R. M., AND DaYhOFf, R. E. (1967) Lancet, 1, 142 (Isolation of diphtheroid organisms from rheumatoid synovial membrane and fluid).

EPSTEIN, W. L., AND Jessar, R. A. (1959) Arthr. and Rheum., 2, 178 (Contact-type delayed hypersensitivity in patients with rheumatoid arthritis).

Finland, M., Peterson, O. L., Allen, H. E., Samper, B. A., and Barnes, M. W. (1945) J. clin. Invest., 24, 451 (Cold agglutinins. I. Occurrence of cold isohemagglutinins in various conditions).

Fiset, P. (1964) 'Serological Techniques' in 'Techniques in Experimental Virology, ed. R. J. C. Harris, p. 225. Academic Press, London.

Fresco, R. (1968) Fed. Proc., 27, 246, abstr. no. 170. (Tubular (myxovirus-like) structures in glomerular deposits from a case of lupus nephritis).

Hotchin, J. (1962) Cold Spring Harbor Symp. Quant. Biol., 'Basic Mechanisms in Animal Virus Biology', vol. 27, p. 479 (The biology of lymphocytic choriomeningitis infection: virus induced immune disease).

Houba, V., ADAM, M., MALAČEK, J., AND TEsáreK, B. (1964) Experientia (Basel), 20, 522 (Delayed hypersensitivity and antibody response in rheumatoid arthritis).

MASI, A. T., Robinson, H., AND HUGHEN, M. (1968) Memphis and Mid-South med. J., 43, 359 (The arthritis research program survey of newly diagnosed arthritis among residents of Memphis and Shelby County).

Meiselas, L. E., Zingale, S. B., LeE, S. L., Richman, S., AND Siegel, M. (1961) J. clin. Invest., 40, 1872 (Antibody production in rheumatic diseases. The effect of brucella antigen).

Norton, W. L., Velayos, E., AND Robison, L. (1970) Ann. rheum. Dis., 29, 67 (Endothelial inclusions in dermatomyositis).

PEASE, P. (1969) Ibid., 28, 270 (Bacterial L-forms in the blood and joint fluids of arthritic subjects).

Rawson, A. J., Abelson, N. M., AND MCCARTY, D. J. (1961) Arthr. and Rheum., 4, 463 (The isohemagglutinin partition in rheumatoid arthritis).

Rhodes, K., Scott, A., Markham, R. L., and Monk-Jones, M. E. (1969) Ann. rheum. Dis., 28, 104 (Immunological sex differences. A study of patients with rheumatoid arthritis, their relatives, and controls).

Ropes, M. W., BenNetr, G. A., CoBb, S., JACOX, R., AND JesSAR, R. A. (1958) Bull. rheum. Dis., 9, 175 (1958 Revision of the diagnostic criteria for rheumatoid arthritis).

SharP, J. T. (1970) Arthr. and Rheum., 13, 263 (Mycoplasmas and arthritis).

Shearn, M. A., Epstein, W. V., And Engleman, E. P. (1963) Proc. Soc. exp. Biol. (N. Y.), 113, 1001 (Antibody response to brucella antigen in patients with rheumatoid arthritis).

Simsarian, J. P., Roth, H., Hopps, H. E., Douglas, R. D., Williams, M. S., and Meyer, H. M. JR. (1970) Arthr. and Rheum., 13, 348 (Serologic and virologic studies in patients with rheumatoid arthritis RA).

Singer, J. M., AND Plotz, C. M. (1956) Amer. J. Med., 21, 888 (The latex fixation test. I. Application to the serologic diagnosis of rheumatoid arthritis).

SMILEY, J. D. (1970) Personal communication.

AND CASEY, H. L. (1969) Arthr. and Rheum., 12, 698 (Decreased CF antibodies in sera and decreased lymphocyte transformation to herpes simplex in patients with rheumatoid arthritis) (Abstr.)

SMITH, C., AND HAMERMAN, D. (1968) Ibid., 11, 842 (Resistance of rheumatoid synovial cells to infection with exogenou virus) (Abstr.).

Stewart, G. L., Parkman, P. D., Hopps, H. E., Douglas, R. D., Hamilton, J. P., ANd Meyer, H. M. Jr. (1967) New Engl. J. Med., 276, 554 (Rubella-virus hemagglutination-inhibition test).

WAller, M., Ellman, H. M., AND TOONE, E. C. (1966) Acta rheum. scand., 12, 250 (Brucella immunization in patients with seropositive and seronegative rheumatoid arthritis).

Warren, S. L., MARMOR, L., Liebes, D. M., AND Hollins, R. (1969) Arch. intern. Med., 124, 629 (An active agent from human rheumatoid arthritis which is transmissible in mice).

WinTrobe, M. M. (1961) 'Clinical Hematology', 5th Ed., p. 1115. Lea and Febiger, Philadelphia. 